Moral Political Economy and Moral Reasoning About Rural India: Four Theoretical Schools Compared

by Wendy Olsen Published in Cambridge Journal of Economics 33:5, 2009

Biographical information: Wendy Olsen lectures in socio-economic research at the University of Manchester. She has a PhD in economics and has written Rural Indian Social Relations (OUP, 1996) and The Politics of Money: Towards Sustainability and Economic Democracy (with F. Hutchinson and M. Mellor, Pluto, 2002).

Email wendy.olsen@manchester.ac.uk

Address for correspondence:

Room G-11

The Cathie Marsh Centre for Census \& Survey Research

University of Manchester

Manchester M13 9PL

UK Phone 0161-275-3043 or fax 0161-275-4722

Note: The support of the Economic and Social Research Council (UK) is gratefully acknowledged. The work was part of the programme of the ESRC Global Poverty Research Group, grant number M571255001.

Keywords: tenancy, pluralism, strategies, moral economy, norms, moral reasoning, sharecropping.

JEL Keywords

B5 - Current Heterodox Approaches; O17 - Institutional Arrangements; O12 Microeconomic Analyses of Economic Development; and O53 - Asia including Middle East 


\begin{abstract}
:
This paper explores a pluralist approach to moral economy in two ways. Firstly, as a review, four major schools of thought on the rental of land in India are described. I focus on their normative and ontic assumptions. Secondly, noting that none of these schools is value-neutral, a plurality of six complex moral reasoning strategies emerge from this review. The advantage of the social researcher doing an overview of these normative positions is that we can compare and contrast the meta-criteria that are used. The six moral reasoning strategies are a neoliberal growth strategy, a human capabilities approach, a redistribution approach, a transformative approach, a social equality approach, and a Pareto-optimality approach. The study of these six strategies leads toward the conclusion that more research on complex moral reasoning strategies is called for, because combining them rapidly leads to difficulties. Scientific research can provide evidence to underpin and shape the moral reasoning that takes place in real-world dialogues and debates.
\end{abstract}

Acknowledgement: Thanks go to Jamie Morgan, David Byrne, and two anonymous referees for their valuable help in constructing the paper. I am grateful to Andrew Sayer who organised a conference on moral economy in Lancaster in 2005 . The paper arose as a product of that conference. Please bring any errors to my attention. 


\section{Moral Political Economy and Moral Reasoning About Rural India: Four Theoretical Schools Compared}

\section{Introduction}

In this paper I conduct a review of some research about rural India in order to develop a moral political economy approach to research. I focus on a series of debates about land-rental in India in its socio-economic context. These debates are partly about land use and land productivity, and partly about the labour relationships in rural areas. My method is to compare the theoretical frameworks and reasoning used by various authors in this literature.

Specific new departures in the paper include stipulating what a moral reasoning strategy is; showing that moral reasoning cuts across schools of thought; and giving examples of bridging between theoretical discourses. The approach used here derives insight from Sayer's (2005) appeal to conduct moral economy studies using empirical data, but I focus mainly on theoretical concerns. The approach is rooted in classic works of moral economy such as MacIntyre (1985), Sayer (2000b), Agarwal (1994), Nelson (1995) and others. MacIntyre and Sayer stress that moral values arise within specific human societies (Sayer, 2000a: 98, 167; Sayer, 2000b), and Nelson has showed that the moral values of economists have non-gender-neutral effects in society. I bring out the relevance of these issues for the economics of rural India. I draw connections between the four schools, show their differences at the evaluative level, and explicitly show that certain moral reasoning strategies are common to two or three schools. In all I describe six moral reasoning strategies. An important point is made about the separation of values from facts. I argue that the claim of a science of facts, separate from value judgements, is not coherent for those who conduct economic research.

Selected research on the rental of land is described in section 2. Here I focus on four main schools of thought: neoclassical economics; new institutional economics; marxist political economy; and the gender-and-development school within feminist economics (see Olsen and Mehta, 2006a and 2006b; Olsen, 2007). Each of the four schools treats poverty differently because they theorise society differently. The relationship between poverty and sharecropping is dealt with most explicitly in the marxist theoretical school, i.e. Marxist political economy, which has borne much fruit in India-based empirical research on sharecropping. ${ }^{i}$ This paper compares that treatment with the normative orientations of the other three schools. In doing so, the neoliberal approach used by neoclassical and new institutionalist scholars is shown to involve two main moral reasoning strategies - a neoliberal pro-growth strategy and the Pareto-optimality reasoning strategy. Both strategies are interesting and merit further attention, but most importantly they illustrate the non-value-neutrality 
of the claims made by these schools. For this reason, section 3 of the paper reviews arguments against the separation of facts from values.

My analysis looks at how different researchers utilise their empirical knowledge to frame and shape their normative questions. Some use economic progress as instrumental to human development (e.g. marxists), while others (e.g. neoliberals) would tend to use human/social development and social capital as a means to economic development. Some Marxists and neoliberal authors would agree with each other that a growing commercial economy has scope for poverty alleviation. Neither of these two sets of authors sees economic change as a zero-sum game. In section 4 I show that the neoliberal moral reasoning strategy depends crucially upon particular open-systems assumptions for its trickle-down argument. Since realists have, so far, tended to characterise neoclassical economics as a closed-system set of arguments (Lawson, 1997), this is rather surprising and has interesting implications.

The advantage of the social researcher doing an overview of normative positions is that we can compare meta-criteria for progress from the neoclassical, new institutionalist, Marxist and feminist schools. (Other schools, such as interpretivism and old institutionalism, can offer further innovations not treated here.) I draw out the moral reasoning strategies, which differ from theoretical frameworks. A moral reasoning strategy is a way of arriving at value judgements based on a particular style of reasoning. Examples are given to illustrate. Explicit treatment of the normative reasoning in the study of sharecropping helps us to engage with sets of specific policy proposals. Agarwal (2003a), for example, draws upon both Marxism and feminism, and builds bridges with neoliberals, when she integrates a series of carefully constructed normative positions with her empirical data.

After describing six from the many moral reasoning strategies that are found in development economics, I suggest that readers may want to combine two or three of these in their research. However there are drawbacks to some of them and difficulties with combining them, which I describe briefly. Notably here the Pareto optimality moral reasoning strategy is challenging to the redistributive moral reasoning strategy.

To use a moral reasoning strategy one needs to be well informed about structures, changes, and differentiated agents within its remit. One also needs to consider wellbeing and harm at different levels of society (e.g. people as well as households). The author of a moral reasoning strategy is likely to place themselves inside the macro scene (and thus to be reflexive). Recognising that moral reasoning strategies are complex helps me to draw upon the four schools of thought presented in section 2 whilst being critical of some ontological errors of the neoclassical school. Both epistemological and normative strengths can be discerned in the resulting pluralist approach. 


\section{Four Major Schools of Thought Within Indian Political Economy}

Dow (2004) argues that a school of thought may overlap in practice and in discourse with others, whilst having some incommensurate conceptual elements. Schools of thought are distinguished not only by their ontological assumptions but also by their traditional or usual normative strategies. I have reviewed four economic schools from a realist viewpoint (Olsen, 2006). The pluralism advocated there is similar to Dow's (2004) proposed pluralism of theory. In the present paper, feminist economics plays an important role. Feminism in economics takes many forms, and of these just one (the 'gender and development' school) has been chosen as a focus of attention.

The four schools will be described with reference mainly to what they have said about rural tenancy in India. This particular literature covers sharecropping as well as cash rentals. Cash rentals have been growing in India but share-cropping is still common. In 1999, about $8 \%$ of the land was share-cropped (Sharma, 2000; Shankar, 1999) and nationally $8 \%$ of rural adults were tenants using rented-in land.i ${ }^{\text {in }}$ predominantly agricultural states like Andhra Pradesh and Orissa the percentage doing tenancy is much higher (11\% and $17 \%$, respectively), according to the NSS 1999. iii

Neoclassical economists (NCE) have written about sharecropping for decades. Tenancy transactions are seen by this school as optimal choices which avoid the use of standard labour-market contracts, e.g. Bardhan (1985); Skoufias (1995); Stiglitz (1974). The idea of an optimising decisionmaker on each farm - the landlord and the tenant - is central to the way neoclassical economists write about tenancy. Stiglitz showed that the landlord's attitude to risk might affect their willingness to rent land, and the share or rent they expected to get. Stiglitz's 1974 article followed a tradition in economics in which all farming rental contracts are explained in terms of landlords' attempts to better utilise their land resources whilst also leading toward the new institutional economics which arose in the 1980s.

Skoufias (1995) works in a primarily neoclassical mode, estimating what labour inputs tenants are likely to put into their land. Tenancy is seen in Skoufias' multimarket model as a way to optimally use one's bullock power, irrigation water, and family labour. Ellis (1993) reviews the neoclassical models of labour allocation and of tenancy. Recent developments since 1985 in neoclassical models treat the family more carefully than did the original 1960s and 1970s work. These developments, known as the 'new home economics', are firmly neoclassical with reference to the market, but they un-bundle the household into a set of individuals, who each optimally decide how to allocate their labour. In this theory, individuals make references to market wages and farm income to work out gender-differentiated opportunity costs. Labour on the rented-in land -- i.e farm labour of tenants -- will 
take place as long as it pays the household better than local wages. The labour time (and gender of farm worker) on rented land is thought to be set to optimal levels, in the context of the leisure and domestic work, and thus to be a rational householdlevel decision.

Both the neoclassical analysis and the new home economics thus have an orientation to the market as the guide to the costs of time and goods; they assume maximising decision makers; they assume all parties to a contract make optimal decisions; and they see the landlord as a person who owns land and for whom it is a rational choice to rent some out. Neoclassical economists tend to make formal algebraic models and then, if there is space, test them using empirical household data. Table 1 highlights neoclassical economists' ontic and normative assumptions alongside three other schools: new institutional economists; marxists; and feminists. 
Table 1: Four Schools of Thought on Rural Land Rentals in India

\begin{tabular}{|c|c|c|c|c|}
\hline & $\begin{array}{l}\text { Neoclassical } \\
\text { Economics }\end{array}$ & $\begin{array}{l}\text { New } \\
\text { Institutionalist }\end{array}$ & $\begin{array}{l}\text { Marxist Political } \\
\text { Economy }\end{array}$ & $\begin{array}{l}\text { Gender and } \\
\text { Development (GAD) }\end{array}$ \\
\hline $\begin{array}{l}\text { Objects of } \\
\text { theory (the } \\
\text { ontic } \\
\text { content) }\end{array}$ & $\begin{array}{l}\text { Individuals, } \\
\text { firms, } \\
\text { landlords; } \\
\text { markets; } \\
\text { demand; } \\
\text { supply }\end{array}$ & $\begin{array}{l}\text { Workers and } \\
\text { landlords as } \\
\text { principal and } \\
\text { agent; contracts; } \\
\text { markets; } \\
\text { decisions; } \\
\text { information }\end{array}$ & $\begin{array}{l}\text { Social classes, } \\
\text { interacting with } \\
\text { castes and state } \\
\text { government }\end{array}$ & $\begin{array}{l}\text { Various types of agent } \\
\text { who reflexively } \\
\text { contemplate the } \\
\text { actions they take and } \\
\text { their effects; men, } \\
\text { women, the state, } \\
\text { traditions, customs, } \\
\text { norms }\end{array}$ \\
\hline $\begin{array}{l}\text { Ontic } \\
\text { assumptions }\end{array}$ & $\begin{array}{l}\text { Individualisti } \\
\text { c optimising } \\
\text { predominates } \\
\text {; market } \\
\text { demand and } \\
\text { supply are } \\
\text { known and } \\
\text { they create } \\
\text { context of } \\
\text { free choices }\end{array}$ & $\begin{array}{l}\text { Modelling iconic } \\
\text { agents gives } \\
\text { worthwhile } \\
\text { predictions; } \\
\text { utility is } \\
\text { mathematizable; } \\
\text { situated } \\
\text { optimising } \\
\text { occurs; }\end{array}$ & $\begin{array}{l}\text { Structures } \\
\text { interact with each } \\
\text { other; agents in } \\
\text { social relations do } \\
\text { not simply make } \\
\text { free choices; } \\
\text { people act } \\
\text { according to their } \\
\text { class interest }\end{array}$ & $\begin{array}{l}\text { Society has interwoven } \\
\text { layers (a depth } \\
\text { ontology; Layder, } \\
\text { 1998); stereotypes and } \\
\text { norms exist; agents are } \\
\text { important actors in } \\
\text { construing social } \\
\text { relations, }\end{array}$ \\
\hline $\begin{array}{l}\text { Normative } \\
\text { assertions }\end{array}$ & $\begin{array}{l}\text { More income } \\
\text { is better; } \\
\text { Pareto } \\
\text { Optimal } \\
\text { changes are } \\
\text { good; } \\
\text { efficient } \\
\text { production is } \\
\text { good }\end{array}$ & $\begin{array}{l}\text { Non-market } \\
\text { production will } \\
\text { tend to be less } \\
\text { efficient than } \\
\text { marketised } \\
\text { production }\end{array}$ & $\begin{array}{l}\text { Structures of } \\
\text { oppression need } \\
\text { to be changed; } \\
\text { changing them } \\
\text { requires } \\
\text { innovative } \\
\text { discourses of } \\
\text { resistance }\end{array}$ & $\begin{array}{l}\text { Women suffer from } \\
\text { both class and gender } \\
\text { oppression; in India, } \\
\text { caste structures create } \\
\text { (bad) pressure on } \\
\text { Hindu women by } \\
\text { privatising their lives } \\
\text { and priorities }\end{array}$ \\
\hline
\end{tabular}

Note: For full references to the literature see Olsen (2006). 
In neoclassical economics, Pareto optimality became a central principle during the $20^{\text {th }}$ century (Pareto, 1909 in Italian, first published in English in 1971). As a moral principle Pareto optimality conceives that a change would be a social improvement if it made things subjectively better for someone but did not make anyone else feel worse off.

New institutional economists (NIE) look at it slightly differently. They model the decisions behind the contract. Most argue that tenancy contracts represent an optimal solution to a game-theoretic problem of simultaneous rational choice of landlords and workers (e.g. Srinivasan, 1989; Genicot, 2002; Majid, 1994). The context is one of risk aversion, uncertainty, and incomplete markets. Much of the ontology of the new theory is the same as in neoclassical economists. However, markets are not assumed to work perfectly, and information enters as an important entity. Both neoclassical and new institutional economic theories have a focus on monetised values, exchange value, and prices in common.

In the marxist school known as marxist political economy (MPE), tenants are seen as part of the working class. They are assumed to be poor workers. They are 'used' by landlords who try to efficiently extract surplus labour and to realize its value in the crop market (Olsen, 1996). Many marxists thought that landlords were blocking the modernization of agriculture. One explanation of blocked technical progress would be landlords' preference for retaining attached labour using usurious credit (Bhaduri, 1973, 1983b, 1986).

An interesting example linking new institutionalism with Marxism is Majid (1994). Majid reviews the declining role of sharecropping in Sindh, Pakistan using NCE and NIE theory. Landholding structures which underlie the decisions of landlord and tenant are critical influences upon whether and how sharecropping takes place. Majid uses detailed empirical data and makes connections with the marxist interest in the relations of production (the third school, below). However, the underlying class relationships remain merely background (1994, ch. 10). Majid focuses instead on tenancy contracts.

Singh (1995), a Marxist writer, describes uneven development where different levels of technology and labour productivity are found within pockets of a single locale (Singh, 1995). In Punjab, says Singh, the landlords use migrant tenants to drive tractors on the landlord's cultivated land but then expect them to hoe their rented plots manually. Uneven development is best seen in class terms, as also argued by Brass and van der Linden, 1998, and by Bhaduri, 1997.

Marxists like these make numerous evaluative assumptions. For instance, they assume that specific structures of class are exploitative and that they involve oppression of the working class. The structures need to be changed. To change them involves generating discourses of resistance. Otherwise capitalists and landlords will convince workers that they have shared interests. Marxists argue that discourses of nationalism and caste can tend to mask and discourage a working class awareness of their own struggle for well-being in a class society (Aloysius, 1995). An overview of this approach to moral political economy is given by Sayer 
(2000), pages 158-171 (ch. 7). Sayer describes traditional Marxism as one form of critical social science with a fairly negative ethic: it is bad for workers to be exploited (Fay, 1987). Sayer says that this moral principle does not open up the wider constructive question of what would be good for workers. Sayer suggests that critical social science is an arid soil for moral economy because there is so much more that needs to be addressed besides the false consciousness of workers.

Table 1 (column 3) summarises the assumptions typically made by marxists in the Indian sharecropping literature. Athreya et al. (1990) is a typical example. Athreya's book combined the neoclassical measurement of land productivity farmwise (similar to Bliss and Stern's village studies) with the marxist study of class dynamics. Thus this work of theirs bridged between neoclassical concepts and marxist evaluative assumptions. By testing the marxist assumptions for empirical validity, Athreya et al. moved them from the status of 'assumptions' toward being 'assertions'. This switch enabled Athreya et al. to carry out interesting empirical work. Compared with neoclassical research, their book is relatively structuralist (i.e. has class structure as a substantive assumption), but compared with Marxist literature their book is open to hypothesis-testing and exploration of their complex mixed (qualitative and survey) data. They found, to their surprise, little economic exploitation by landlords via usury. Whilst this refuted one assumption of Marxist school, the research did not go so far as to reject the structures of class as a useful mechanism for describing the rural society. While Athreya, et al., are on the fringes of Marxism in India, and Bhaduri (1983b) is much closer to the core (usual) approach, numerous authors have been experimenting with variants of Marxism. Kalpagam studied urban planning from a Marxist viewpoint (1994); Mies explored gender issues from a Marxist viewpoint (1998); and Brass rejects postmodernism and empiricism in the study of rural Indian labour through his substantial, extended Marxist research (2001).

Feminist writings from the Gender and Development (GAD) school form the fourth school. GAD experts draw upon Marxism but also focus intensely upon women, gender relations (which are seen as a social structure), patriarchy and the micro-macro linkages of the world economy. Foremost here is Mies $(1982,1998)$ whose initial Indian monograph showed female lace workers being exploited through both class and trading relations whilst also doing domestic work that created, for them, a double burden. Mies, (1982), like Kabeer writing much later (1995), broke down the class approach into a focus on differentiated women whose class/gender position was doubly weakened them. An underlying structuralism is typical of feminist 'gender and development' (GAD) writing but allows for transformative influences of agency (Beneria, 1979, 2003).

Mies argued in a later book (1998), that many housewives are being used by the world economy. Mies said that the double burden on women could only continue to perpetuate their subordination if women and men continued to co-participate in it. The normative viewpoint here is to try to change women's cultural and normative expectations. Both Mies and Agarwal have advocated strong feminist demands as a policy platform grounded in 
empirical work (Agarwal, 1994). Mies particularly wanted Indian women to resist their double exploitation.

Let us focus on the ontic assumptions here. These feminists assume that stereotypes and norms exist, and are gendered. However they see them as malleable, too. Their view of 'preferences' is very different from that of economists (of the NCE and NIE schools): preferences are ever-changing and changeable. Mies and Kabeer argue that women and men combine as agents in ongoing relations to create the structures that bind them. They can recreate and change the structures. Terrific optimism is combined with graphic description of the kind of exploitation that is actually continuing.

For instance in India, a series of qualitative studies show how Hindu women are still conforming in many ways to Hindu stereotypes. Many rural women believe that their private lives are more important than doing public activity; that their marriage is their main hope in life; and that their children are their main achievement. One author which summed up local voices on the social expectations facing Hindu women put it this way:

The gender relationship entailed by the division of work according to sex . . . reveal(s) the structural relationship that prevails between the two genders: Masculine Role: [being] owner, boss, leadership . . . manager, he who holds power; ... Feminine Role: [being] domestic, subjection, servant, servility, vileness, slavery [etc.]

Poitevin and Rairkar, 1993: 159-160, translated from the language of Pune, Maharashtra, India.

Poitevin and Rairkar argue that the cultural norms affect the working of rural labour markets. Muslims have also been experiencing a patriarchal gender regime in rural India (Jejeebhoy and Sathar, 2001). Purdah, the practice of requiring women to cover their bodies so as to cover their skin and conceal their form, also refers to male control over women's movement outside the home. Under purdah, women are seen as protecting the family's honour. Purdah is in part a matter of women being self-disciplined in their 'good' behaviour. The Muslim and Hindu traditions of purdah were summarised in depth by Agarwal (1994) across the four South Asian countries India, Bangladesh, Pakistan and Sri Lanka. Purdah is differentiated regionally in its meaning and coverage. Purdah is not restricted to any one or two ethnic groups. Agarwal argued that purdah is being challenged by some women, so that it is continually changing. Gender stereotypes affect the labour market by shaping what people feel can or cannot be done by women. Most tenants attribute land ownership to the man of the household, and women's roles in dryland agriculture are widely considered to be restricted to labouring and domestic work.

Kalpagam (1994), another GAD feminist, has built a conceptual model to enable policy makers to examine change in the gender regime and class relations. Kalpagam's model is a 
transformational model of social activity (see also Archer, et al., eds., 1998). P. Swaminathan (2002) illustrates a structuralist approach to gender inequality - in the sense of taking class, gender, and ethnicity as three social structures of equal importance ${ }^{\text {iv }}$ - combined with great sensitivity to social change as it affects women's roles.

When these feminist writers write about tenancy, they are looking at it sociologically and are focusing on the gender regime involved. All feminists take a strong interest in women's farming work and its remuneration. ${ }^{v}$ Tenants' work was described in detail, for instance, by Dacorta and Venkateswarlu (1999). The lack of measurement of the unpaid labour time doesn't change the reality that the work has been done. Dacorta observed that the women of tenanting households in southern Andhra Pradesh also do unpaid domestic work and cowrelated work with dung at the landlord's house. I also interviewed women in the same district who did these tasks from a position of utter powerlessness vis-a-vis their landlords in 1995 (e.g. the landlord owned the worker's hut-plot). Marxists and neoclassical economists alike tend to use a household unit of analysis and thus ignore gender difference in the experience of tenancy. Decision-making and money-earning is often attributed to men. Furthermore the idealised household was perceived to be male-headed. Feminists argue that such assumptions are limiting and damaging to women.

There are a number of places where the first three of these schools overlap. For instance, Bhaduri, a leading theorist of the Marxist political economy school, can be found exploring the contractual arrangements in terms similar to those now used in new institutional economics.

Loan arrangements can . . change in many ways, which have been so simplistically captured in our model in terms of a single parameter representing the own rate of interest. . . [and in a footnote] a new loan arrangement - the socalled managed loan - which has become widely prevalent in place of traditional consumption loans in Haryana. . .

(Bhaduri, 1983b: 66, footnote in original).

Here Bhaduri blended the formalised procedures of economic orthodoxy with the substantive assumptions and empirical interests of classical Marxism in India. Assets and resources are distributed differently to the classes, and each class acts in its own interest, he says. The landlord class protects its interest, even sometimes at the cost of lower productivity, he said. They may think that lower productivity can be offset by higher usury income combined with the rental income. Therefore, under his assumptions, resistance to new technology might be the result.

Here Bhaduri thinks he has caught the neoclassical economists in a bind: how can rational behaviour in the landlords' interests be economically irrational? Because their 'interests' are sectional, whereas neoclassical economists' notion of rationality usually considers only the 
aggregated outputs of agriculture. A rise in the capitalist landlords' share is what Bhaduri thinks the landlords work toward, whereas a rise in the total product is what orthodox economists usually assume is desirable. Pareto optimality is the main criterion of net value used by orthodox economists (see Table 1, Row 3).

Orthodox economists rule out exploitation discursively by focusing on aggregate supply and demand for crops and for land. Several new institutional economists have focused on the point that the tenant has chosen to make the contract (e.g. Srinivasan, 1989; Srinivasan and Bell, 1989). In other words, even if the tenant loses out in the short run, they have chosen the contract - so by deduction, there must be some benefits in the contract that they prefer having it over not having a rental contract.

This is a tautology. But Bhaduri, too, can be accused of a tautology. His prediction in 1983(b) turned out not to match the growth performance of northern Indian agriculture. Landlords and capitalist farmers did pick up new technologies, in spite of their land rental arrangements (Stiglitz, 1986; Bhaduri, 1986). There were two misunderstandings here. Firstly, Bhaduri's model was intended to examine the power landlords have. Its weakness was perhaps not being well-grounded in a specific place/time. As a universalistic formal model, it is not clear where in India it would apply. Where would we look for real instances of these usury relationships? When Athreya looked for them in Tamil Nadu, his team didn't find much usury. When I looked for them in Andhra Pradesh, I did find usury but it was carefully hidden. Only detailed field research could uncover it because there is a law against usury. I also found that villages just $2 \mathrm{~km}$ apart had very different usury situations because of localised bankers' competition against moneylenders (Olsen, 1996). There are empirical differences over space and by class in the real power of landlords to control the prices they pay for supplies of crops and to charge high interest. In the 1980s a strong paradigm opposition emerged: Stiglitz bypassed the question of power by arguing that is was not operationalizable. But Bhaduri's advocated the study of rural class power, and his approach needed concrete local or regional evidence (Stiglitz, 1986; Bhaduri, 1986).

Secondly, Bhaduri's model meant to focus on class interests. The misunderstanding that occurred was that Bhaduri's contextual factors - feudalism in northern rural India; traditional respect paid to the landlord; and caste-based social obligations - were ignored by orthodox economists. By reducing the world to the economic competition of classes, economists, including Bhaduri, over-simplified the optimisation problem. The general trend, led by Stiglitz (1986), was to show that Bhaduri was factually wrong. This ignored Bhaduri's Marxist agenda of challenging landlords' power. This agenda was progressed by Marxist authors like Ramachandran (1990). In West Bengal the Communist Party of India (Marxist; CPM) implemented strong land reforms and increased the rights of tenants (Banerjee, et al., 2002; Basu, 1992). In this sense Bhaduri's model was influential within India until structuralism's ascendancy there ended around 1991. The CPM has had parliamentarians in various states and in the national parliament through the whole period. 
Among the Marxists, quite a few carried out detailed fieldwork and offer qualitative analysis, or at least vignettes, as part of the research outputs. Here they tend to overlap with and blend into the feminist authors' work. For instance, Mencher (1978) worked in a structuralist tradition focused on caste and class structures in the agrarian economy. She describes in detail the motives and perceived constraints of a series of individuals who did farming in southern India (1978: 208-210). Menchester describes what is 'necessary' from the worker's subjective perspective. She brings to our attention the fact that workers' choices are made in a context of unfreedom.

Ganeshan has 1.5 acres of varam [rented] land to look after. He and his wife work for one to two months in a year for others on a daily basis. They cannot do more because of his varam land. . . . It is clear that his first priority is looking after his varam land. Yet it is necessary for him to hire others to work his land as well. . . Munuswami is a Harijan from Pacciyur. He owns . . . He ploughs ... His wife also works for others when she is not pregnant.

Mencher, 1978: 208-209.

Another structuralist, Epstein, writes mainly as a class-oriented structuralist but also takes into account a number of neoclassical economic facets of agriculture such as productivity and marketing (1962; 1973; 1998). Epstein draws strongly normative conclusions in one monograph (1973, last chapter). In her view, growth in India's agricultural output would make it possible for tax to be collected from the big farmers. This tax money could support redistributive expenditure. Thus her empirical work led her to a detailed normative conclusion. However she stayed within the economic (monetised) realm in drawing her normative conclusion.

Another example illustrates the Marxist standpoint. Ramachandran (1990) examines unfree labour as a phenomenon within the rural working class. Some workers agree to permanent contracts and other forms of bondage (he says, with regard to people in Tamil Nadu), even after the end of traditional patron-client relations. He argues that Marx said the working class, as a class, is unfree vis a vis employers, but the point Ramachandran adds is the persistence of bondage even in the recent experience of capitalist farming in south India. Ramachandran provides detailed family case histories. He works from his vast primary data toward a conclusive grasp of the reasons why bonded labour is persistent:

Why do workers agree to give an employer a right of first call over their labour power and submit to the kind of servitude that such a relationship entails? There is no legal coercion for them to do so ... The most important reason is, of course, that workers are compelled by poverty and unemployment to seek different ways of ensuring that they get wage employment whenever it is available and of ensuring subsistence at times when there is no employment to be had." 
Ramachandram, 1990: pp. 253-254; see also p. 181 et passim.

I will use Ramachandran and other examples in Table 2 and in section 4 to illustrate alternative modes of complex reasoning.

Table 2: Complex Moral Reasoning Strategies in the Study of Tenancy

\begin{tabular}{|c|c|c|c|c|}
\hline Reasoning Used: & $\begin{array}{l}\text { Neoclassical } \\
\text { Economics }\end{array}$ & $\begin{array}{l}\text { New } \\
\text { Institutional } \\
\text { Economics } \\
\end{array}$ & $\begin{array}{l}\text { Marxist } \\
\text { Political } \\
\text { Economy }\end{array}$ & $\begin{array}{l}\text { Gender and } \\
\text { Developmen } \\
\mathrm{t}(\mathrm{GAD})\end{array}$ \\
\hline $\begin{array}{l}\text { Neoliberal open- } \\
\text { systems reasoning }\end{array}$ & $\begin{array}{l}\sqrt{ } \text { Skoufias, } 1995 . \\
\text { Bliss and Stern, } \\
1982 .\end{array}$ & $\begin{array}{l}\sqrt{ } \text { Genicot, } \\
\text { 2002; Stiglitz, } \\
1974 .\end{array}$ & & $\begin{array}{l}\sqrt{ } \text { Agarwal, } \\
2003\end{array}$ \\
\hline $\begin{array}{l}\text { Human capabilities } \\
\text { reasoning }\end{array}$ & $\begin{array}{l}\sqrt{ } \text { Sen, 1979, 1980, } \\
\text { 1993; Drèze and } \\
\text { Sen, 1996: 1-8, 137- } \\
\text { 161, 294-300. }\end{array}$ & $\begin{array}{l}\sqrt{\text { Stiglitz, }} \\
\text { 2002b. }\end{array}$ & $\begin{array}{l}\sqrt{ } \\
\text { Ramachandran } \\
, 1996 .\end{array}$ & \\
\hline $\begin{array}{l}\text { Redistributive } \\
\text { reasoning }\end{array}$ & & & $\begin{array}{l}\sqrt{ } \text { Epstein, } \\
1973 .\end{array}$ & $\begin{array}{l}\sqrt{ } \text { Agarwal, } \\
2003 \text { (and } \\
\text { elsewhere). }\end{array}$ \\
\hline $\begin{array}{l}\text { Transformation via } \\
\text { praxis reasoning }\end{array}$ & & & $\begin{array}{l}\sqrt{ } \text { Bhaduri, } \\
\text { 1983a and b, } \\
\text { 1986; } \\
\text { Ramachandran } \\
\text {,1990. }\end{array}$ & \\
\hline $\begin{array}{l}\text { Social equality } \\
\text { reasoning }\end{array}$ & & & & $\begin{array}{l}\sqrt{ } \text { Jackson, } \\
1996,2002, \\
2003\end{array}$ \\
\hline $\begin{array}{l}\text { Pareto-optimality } \\
\text { reasoning }\end{array}$ & $\begin{array}{l}\sqrt{\text { Skoufias, } 1995} \text {; } \\
\text { Bliss and Stern, } \\
1982 .\end{array}$ & $\begin{array}{l}\sqrt{ } \text { Srinivasan, } \\
\text { 1989; } \\
\text { Srinivasan } \\
\text { and Bell, 1989; } \\
\text { Agrawal, } \\
1999 .\end{array}$ & & \\
\hline
\end{tabular}

Note: A tick mark $\sqrt{ }$ indicates that the reasoning is found either implicitly or explicitly in this literature. The reference given is to one example illustrating the school in the selected case of rural south Indian share-cropping and tenancy. 
So far I have reviewed four major schools in the literature (NCE, NIE, Marxists, and feminists) and then provided a few examples illustrating overlap between the schools. I have called these overlaps 'bridges' (Olsen, 2006), building upon Walby's notion of avoiding epistemological chasms (Walby, 2001). Bridges, where academic discourses are made to overlap, increase commensurability. In the tenancy literature partial incommensurability exists, while there are cross-school overlaps of substantive (ontic) assumptions.

In the next section I argue that all four schools' authors incorporate typical ethical, evaluative, and normative elements. ${ }^{\text {vi }}$ My argument against the separation of facts and values is based on a realist recognition that all discourses embody and bear values and evaluations (Fairclough, 2001). The need for economists to be self-conscious about their own discourses is widely recognised by Marxists and feminists in India (Kapadia, ed., 2002; Mies, 1998). I suggest that ethical reflection is also desirable in NCE and NIE. In section 4 I will survey the specific moral reasoning strategies that are currently in use by all four schools, and then conclude the paper. Since the separation of facts from value judgements is commonly assumed to be possible in NCE and NIE, yet these economists promote two specific moral reasoning strategies, an inconsistency arises which needs to be resolved. ${ }^{\mathrm{vii}}$

\section{Challenging the Supposed Separation of Positive and Normative Claims}

The fact-value distinction has played some role in every form of positivism in economics. ${ }^{\text {viii }}$ A recent economics textbook distinguishes 'pure value judgements' from expert claims about inefficiency (Begg, Dornbusch and Fisher, 2005: Chapter 15). The former are outside economics, while the latter are a question of fact, say Begg et al. (ibid). This kind of reasoning portrays many forms of economics as a factual science in which subjectivity plays no part (Hands, 2001).

Sen argued against the separation of facts and values (Sen, 1980; Sen, 1979; Walsh, 2003: 344) by arguing that from differently experienced lives, human standpoints tend to differ. A set of situated viewpoints can clash significantly on a variety of fronts (ibid., and Sen, 1993). Each author/speaker chooses what to present/represent by applying their background values (Sen, 1980). Sen's (1993) approach thus bridges with feminist and constructivist approaches by arguing that value-neutrality is not possible within economics research. Instead, Sen says, research topics and methods are chosen to promote certain interests or aims. Descriptions reflect choices (Sen, 1980). It is important to enumerate some reasons behind the rejection of the fact-value separation argument (see also Olsen and Morgan, 2005; Morgan and Olsen, 2007). The main reasons to accept that descriptive and evaluative claims cannot be seen as separate are:

3-1) Firstly, descriptions of society are thick with interpenetrating meanings. Some of these meanings carry value judgements. These meanings are not merely conventional but also involve speakers in making ethical judgements (Walsh, 2003; Putnam, 2002). Thus for example if one says it is 'optimal for the household' to have women do subsistence farming 
and men do cash crop tenancy, one invokes the judgement that women should not do cash cropping. More subtly, one accepts the background norms which are part of the scene being described. The value judgement may be implicit, but it is still there.

Nelson argues, furthermore, that having and knowing about feelings is an important part of what (all) economists actually do (Nelson, 2003; Nussbaum, 2001). The idea of an optimal division of labour depends on people feeling that a division is good. Feelings involve affect. Other feelings in the tenancy literature relate to the approval of sufficiency of food production; a desire for tenants to have autonomy over farm production decisions; and worries that the tenants are being exploited. Approval, desire, worries - these are evaluative components of economists' typical arguments. In Begg, et al.'s welfare economics, 'inefficient' outcomes are evaluated as bad. So Begg et al. make evaluative statements (in reality) while pretending to be making statements of fact. Morgan and I have argued that Begg et al.'s approach pretends to achieve a God's-eye view of reality, whereas economists really only achieve a positioned view (Morgan and Olsen, 2007).

A description such as 'tenants choose to become bonded to their employers by debt under conditions A, B, and $C^{\prime}$ (which is the main theme of Srinivasan, 1989) has rich normative connotations. It hints at an evaluation on Srinivasan's part that choice is good, and it asserts that if something is chosen then it is good for the chooser. The intrinsic importance of aiming representations (of the economy) at 'valued ends' is argued by Mäki (1994: 243) and by Nelson (1995). But Srinivasan's argument avoids stating what the 'valued ends' are that he seeks (see O'Neill, 1998, for a discussion of this subjectivism). Thus Srinivasan's description (1989) has a pretense of value neutrality that does not meet the standards of scientists like Mäki (1994), Nelson (1995, 2003), or Caldwell (1994) for more exact and explicit statements of what is being hoped for.

Supposedly positive statements reveal an author's beliefs and some of their preferences.

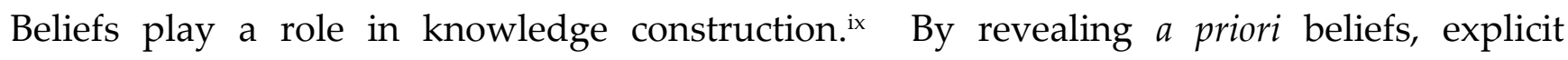
knowledge claims create an arena for contestation. Caldwell's variant of critical rationalism poses this arena as a constructive field for research (1994: 149-50). Aldridge (1993) has contributed to this particular approach to science. She has shown that removal of the author's personal views from scientific writing is a way of trying to mask the author's evaluative commitment to the views they are conveying. Development economists usually avoid using ' $\mathrm{I}$ ' or 'I think', and thus illustrate the masking. Nevertheless a reader can work out what their preferences are. Purportedly making positive statements, an author reveals their ontological assertions. Their preference for these particular substantive assertions often reflects deeply held beliefs which are, in part, evaluative.

3-2) A second argument is that the evidence used during arguments is subject to a series of measurement issues which invoke evaluations and values. Frequently in economics, operationalisation cannot factually, simply, or exactly represent reality in measures. This argument is surveyed by Pawson (1998) and by Pawson and Tilley (1997: 156-163). Pawson 
and Tilly (1997) focus on two hiatuses that affect the capacity of measures to represent reality. (a) Lay actors' knowledgeability is limited and may exclude some important causal mechanisms (ibid., p. 163); (b) interviews and surveys involve negotiation of differences between researchers' discourse and lay actors' discourse, changing both (ibid., pgs. 156-7). ${ }^{\mathrm{x}}$ Realists generally take Pawson and Tilley's view and therefore tend to advocate scientific (critical) realism instead of naïve empirical realism (Sayer, 2000; Danermark et al., 2001). Therefore the choice of a measurement metric, and the use of one theoretical framework, reflect the evaluative judgement of the researcher. Williams (2005) stresses that these premeasurement decisions are value judgements as well as being scientific judgements.

3-3) Thirdly, ethical reasoning is normally complex and not simple, so researchers' ethics as revealed through their writing or speaking are not simply a series of personal or facile preferences. Instead, what can be detected is often a coherent, reasoned set of views. Wolfe (2001) shows that people's reasoning about ethics is very complex. Utilitarian logic would be one example of complex practical reasoning. ${ }^{x i}$ Feminist reasoning would be another example (Babbitt, 1993). I will expand on this general point in the next section. The complexity and challenges of moral reasoning are stressed by Wolfe (2001) and by Sayer (2000b). Specifically moral reasoning is invoked whenever someone considers the needs or preferences of more than one individual in a human society. ${ }^{x i i}$

Passing now beyond the theory of individual rationality. . . we need to know what distinguishes moral norms from other criteria of assessment. Moral evaluation seems to be concerned most centrally with the assessment of conduct or character where the interests of more than one individual are at stake. Further, moral evaluation assesses actions or outcomes in a peculiar way: The interests of the strongest or most prestigious party do not always prevail. . . (Railton, 1997: 149150).

Thus ethical reasoning is widespread in economic commentaries which try to bring into view the needs, interests and desires of a whole range of people.

In summary, the three arguments against the supposed possibility of fact-value separation show that it is not possible to separate facts from values in making knowledge claims. Further support for these arguments arises in philosophy (Putnam, 2002, 2003), in psychology (Brinkmann, 2005), in feminism (Lloyd, 1995), in nursing (Rolfe, 2006) and in management studies (Ryan, 2005). The systematic philosophical study of value neutrality by Lacey (1999) attempted to allow value neutrality's possibility to show through using the strongest possible arguments in its favor. Lacey's study showed that deep underlying value stances are inevitably invoked even when one is attempting to be impartial, distanced and/or neutral in a particular empirical stage of research. My detour into the arguments against the separation of facts from evaluative statements has prepared the ground for a description of the various complex moral reasoning strategies. 


\section{Complex Moral Reasoning}

All four major schools of thought use strategies of moral reasoning, and by mixing strategies the reasoning becomes complex. Table 2 summarises the six main strategies found. I refer to the India-based works in order to give concreteness to the argument. Before listing the six strategies, let me define a moral reasoning strategy more explicitly. A moral reasoning strategy has two components. Firstly it is a method of comparing states of affairs in terms of their effect upon, and value for, a variety of human beings within those different states of affairs (Railton, 1997). Secondly, it also presupposes a subject position for the author or speaker. They can, for example, either be reflexively aware of their position in society, and thus aware of their own subjectivity, or they can pretend to have a power of over-arching knowledge, or some variant on these two positions. Because people use different combinations of these two dimension, a wide variety of ways of doing moral reasoning are in practice found in society (Wolfe, 2001). xiii A moral reasoning strategy can refer to situations in the past or present, or it can use hypothetical and possible futures as counterfactuals (Patomaki, 2006; O'Neill, 1998). Ethical thinking in general is highly variegated (Singer, 1994), but by listing six moral reasoning strategies I am creating a typology of patterns of thought. The 'moral' content of the strategies is specifically the way in which a knower - e.g. a researcher - is prescriptive about states of affairs, roles, rules, institutions or structures in a society. The 'moral' content I looked for was not just the personal preference or choice of the author but a wider sense of ways that typically are used to judge what is good. As Nussbaum explains, a society that enables people to be compassionate may be a good society but that depends on how compassion and goodness are (in practice) encouraged by the society (2001: 415-416). In this section I am looking at the researcher as a person whose moral thinking may be of better or worse quality, but I am also seeing moral reasoning strategies as having histories and being embedded in standardised ways of seeing the world according to schools of thought. Thus in addition to mentioning individual authors' prescriptions I am also noting the social trend that typically uses such moral reasoning strategies.

In what follows I describe the competing strategies actually found in the Indian tenancy debate. ${ }^{\text {xiv }}$ Within this scene, the first moral reasoning strategy is a neoliberal growth strategy which focuses on marketised activities of individuals and argues that economic growth is good. This argument, far from being a closed-system argument as Lawson (1997) strongly suggests, allows for open-ness of the economic system through its evolution toward greater production and higher incomes. Because of this assumed economic open-ness, growth with equity has been assumed to be a possibility. Incomes were not seen as necessarily a zero-sum game, and land productivity in particular was not perceived as a zero-sum game. The growth of production is seen to create opportunities for higher incomes. The neoliberal orientation toward the benefits of growing markets is widely seen in development economics textbooks (Todaro, 1997) and in the study of peasant economies (Ellis, 1993). 
Three neoclassical authors who used the neoliberal reasoning strategy in a tenancy context are Skoufias (1995) and Bliss and Stern (1982). Skoufias looks at the labour cost tradeoffs for farmers in deciding what labour to hire, but generally he meanwhile assumes that the farmer aims for higher production and productivity. The ability to move the production function outward is a neoclassical assumption that fits with neoliberal moral reasoning. Bliss and Stern conducted village studies to question whether it was true, as Marxists had suggested, that exploiting labour was in itself a priority for large Indian farmers. These landlords, they showed, aimed to increase production and did indeed raise land productivity over time. For these authors, economic growth is seen to promote opportunities for farmers to become better off. In Table 2 I denote these authors as using two moral reasoning strategies, because they also use a second strategy (Pareto optimality moral reasoning; see below) which is separable from the neoliberal growth assumptions.

The second moral reasoning strategy is the human capabilities approach, associated with Sen, Nussbaum, and Alkire and Black (1997), focuses on a wide range of social and personal outcomes including empowerment (Nussbaum, 1993; Anderson, 2003). For such authors, the human capabilities underly good conditions which make possible a variety of functionings. Both capabilities and functionings vary from one society to another, but the capabilities are the more fundamental of the two and can be specified in a list (argues Nussbaum, 1999, 2001) in order to guide moral thinking about how best to organise a polity so that everyone has the basic or core capabilities (Anderson, 1993). This approach, like the neoliberal approach, assumes that society is an open system, so society can change. For neoliberals change occurs in the economic and commercial sphere, but for the human capabilities school, change also occurs over time in the area of customs and social norms. Aspects of achieving human capabilities are both good-in-themselves and also sometimes good as a means to other ends (Anderson, 1993, chs 5-8). Nussbaum, an important proponent of human capabilities reasoning in general, argues that owning land is a fundamental human capability (Nussbaum, 1999, and Nussbaum, 2001: 416-420). Human capabilities moral reasoning argues that a situation in which women and men can, and do, own land or control their rented land is better than one in which people who want to own or control land are restricted from doing so. In India 30\% to $40 \%$ of the population are landless, so for India, this human capabilities approach authorises doubts about the rural economic structure. Sayer (1992: ch. 3) used a tenancy example explicitly in order to expose what structures are and what effects they have. This led toward his argument that values are implicated when structural positions are being described by people within the social system (Sayer, 2000b). Nussbaum's advocacy of the right to own land both evaluates land-owning as good for people, and landlessness as bad. Her argument leads toward the assessment that landlessness is a political issue since it causes people to suffer.

My first detailed example of the human capabilities reasoning strategy in the tenancy context is Sen, who has made a gradual transition from neoclassical economist (Sen, 1964 and 1966) to a broader human development orientation. His early work examined the relative productivity of small peasants and large landlords in India, reflecting typical neoclassical 
topics and methods of research. Sen then introduced the human capability reasoning strategy explicitly (1979, 1993). His more recent work, which still has many neoclassical characteristics ${ }^{\mathrm{xv}}$, is aimed explicitly at improving human capabilities both as ends in themselves (expressed as functionings) and as means to further development (Sen, 1996: 1-8; Dreze and Sen, 2002).

A second example is Ramachandran, who has specialised in field research on unfree labour in the context of landlordism in south India (1990). Ramachandran has used concepts of real harm and the alleviation of human suffering throughout his work (1990, 1996), thus implementing a human capabilities reasoning strategy. Ramachandran (1996) published detailed work on India in a book edited by Sen. The feminist Jackson also appears to be influenced by human capabilities reasoning (2002, 2004). Jackson explicitly rejects excessively universalistic moralizing (see also Jackson and Pearson, eds., 1998) and stresses the locality specific nature of existing social norms. Her work is consistent with Sen's positional objectivity (1993) and thus gives us a stimulating example of the human capabilities reasoning strategy in operation.

The human capabilities approach is being diversified through a lively debate at this time (see e.g. Journal of Human Development 2007). While it may be hard to pin down, it is an important area of development studies where moral economy and economic explanations are able to meet in a dialogue. The Jackson viewpoint (or anthropological position) is that local, contextual information is necessary for this dialogue to be well informed. Thus the 'Gender and Development' school has challenged the universalism of the other schools of economic thought.

The third moral reasoning strategy is the redistribution approach. Whilst in economics generally this is illustrated by taxation and welfare economics, in land tenancy it is focussed on either land redistribution, land ceilings, or income redistribution. The redistribution approach can aim to change control over water and other natural resources as scarcities grow; it aims for structural equality; it may foster taxation. Examles include the Marxists named earlier, and Epstein (1973). Sen (1979) also bridges into this approach, as evidenced also by the empirical work of Dréze and Sen $(1995,1997)$.

A good example is Epstein (1973), who openly advocated higher taxes on India's larger farmers. The redistribution of land has also been a redistribution-oriented policy in India for 55 years. Sengupta and Gazdar (1996) give a review of these policies in West Bengal (1996: 136-162), pointing out that the redistribution of land can cause a redistribution of income but not necessarily a very large one. Agarwal (2003a) advocates giving women access to land, including via land rental as well as increased personal access to inherited land. Agarwal is aware that redistribution of land from men to women would tend to individualise ownership, and that traditions of dowry and inheritance have ownership located in the patriarchal household (Agarwal, 1994). Such proposals as hers are interesting and often controversial. They encourage an explicit debate about ethics rather than merely a factual 
debate about explanations of productivity. Most importantly, Agarwal argues that controlling land is empowering for women.

The fourth moral reasoning strategy is transformation via praxis. This strategy is characteristic of Indian Marxists and critical realists, and has three components - diagnosis, consciousness-raising, and praxis. First, the analysts diagnose the changing class structure of a country in its context, then they raise consciousness of class and crisis by disseminating a concretely grounded political economy interpretation, and finally (thirdly) they expect agents to be able to integrate these discoveries into their own praxis (transformative action). Praxis reasoning is not just about comparing states of affairs. It is also about encouraging a change in how states of affairs are characterised. Brass (2001) is a good illustration. He spends a whole article taking up the discursive positions of other historians, criticising them for empiricist and reductionist errors. For such Marxists, improved theory is a part of improved social and collective action.

In this approach the location of the scientist within the social system is explicit. The social struggle for improvements in living conditions is envisaged mainly as a class struggle in which scientists engage along with workers (Bhaduri, 1983a). The suffering caused by the ways that pre-capitalist and capitalist modes of production interact are exposed by experts for the good of all (e.g. Ramachandran, 1996: 224; 300-325). The critical realist interpretation of the transformative approach stresses the general, intersecting, nature of 'social structures', thus placing gender, patriarchy and ethnic social relations on a par with (and interacting with) class structures (Bhaskar, 1998; Sayer, 1992; Chindarkar, 2007; Hogger, 2004 ).

Besides Brass and Bhaduri, Marxists who use transformative moral reasoning to study the rural labouring scene include Venkateswarlu and Dacorta (2001). Their reasoning takes the form of comparing the current reality with a counterfactual state where structural inequality is reduced. In these writings, evidence about the current reality is marshalled, and a discussion of policy options for reducing hurtful inequalities of gender, caste, and class takes place. The authors stress that the agents of change are the actors within the scene, not just an external state organisation. Many of the authors have themselves worked within the agrarian systems which they are describing. Their view is that attempts to improve these systems aim to transform poor people's lives and, necessarily, at the same time change their relationships with others (Bhaskar, 2002). Explicit recognition of transformation within open systems is found among those who stress the need for recognising emotions - such as caring, sympathy, and suffering (Nelson, 2003) - not only on the part of lay people but in ourselves as researchers, too (Giri, 2004: pg 355).

The fifth moral reasoning strategy is the social equality approach which aims for pluralism and mutual respect among sub-cultures. Authors using this strategy want to recognise difference, as exemplified by Jackson's anthropological detail (2003); see also Rew and Khan, 2006, for a general presentation of the arguments for respecting regional cultural difference and respecting anthropological expertise about difference. This approach requires a 
temporary muting of the academic voice and is highly attuned to lay normativities and difference. Promoting social equality requires recognising the rights and desires of different sub-cultural groups. The moral aspect of this reasoning strategy is a meta-morality in which cultural relativism about 'others' cultures' is combined with a meta-value that favours tolerance and mutual appreciation of difference. In social theory, Habermas (1996) illustrates this viewpoint.

In the land rental sphere, the social equality moral reasoning strategy is exemplified by Jackson (2003), who uses anthropological detail to argue that a risk of harm is attached to the redistributivist moral reasoning. Jackson suggests that one policy does not fit all cases, and that cultural factors in Hindu and Muslim patriarchy should not be ignored even if researchers do not agree with each culture's dominant normative values. Jackson warned that harm can come to women if outsiders promote specific challenges to patriarchy.

Finally, the sixth moral reasoning strategy is a subjectivist Pareto-criterion based approach. Pareto optimality reasoning follows the usual strategy of orthodox economics in making comparisons of social welfare through comparing states of affairs using a Pareto criterion. The result is typically, in part, dependent upon an aggregation of people's individual subjective well-being. The Pareto criterion says that any strategy of improvement offered by anybody is potentially valuable as long as (a) no one is harmed by it, and (b) no farm or state or region or household loses out as a result. Building reservoirs, de-silting old tanks, and improving the usability of local water reserves - e.g. with improved pipes or canals - are examples of actions that are widely thought to be Pareto optimal compared with doing nothing. For most authors using this strategy, the knowledge of harm arises from feelings of harm which rest in the individual's subjectivity. Models of equilibria tend to assume that Pareto-optimality depends on not harming subjects in hypothetical experiments that use permutations of a model (not of reality). Thus Pareto-optimality logic rests upon avoiding harm, and can be inserted into a variety of models, explanations, counterfactual thought experiments and comparisons.

In the study of land reform and land management in India, Mearns (1999) illustrates the Pareto optimality moral reasoning strategy. Mearns presented the World Bank's analysis of land issues in India by arguing a complex case for reforming the management of land records rather than reforming land ownership itself. His case is presented from a new institutional economics point of view. The argument is that improved and computerised land records can help both tenants and land-owners to better utilise the land. Those who rent will have clarity about their rights; if they buy, the purchase will be recorded clearly and publicly. Those who farm their own land will have clear ownership rather than experiencing court cases over control. (These cases are indeed common.) The land records are in a mess to different degrees in the various locales and regions of India. For instance some ex-Zamindari areas have a different record-keeping and land transfer system to nearby ex-ryotwari areas. Mearns argues that improvements that use computers can only improve matters and can harm no one. By contrast, he says, land reform has clear losers who would need to be 
reimbursed (either by payments for land they lose in a land reform, or by compensation for losing the right to evict their tenants if there were a tenancy reform). The Pareto optimality argument is pursued by examining the relative costs and benefits to different parties from the various land policy options.

A full discussion of Mearns' position goes beyond the remit of this paper. It is interesting to note, though, that Mearns represents the current NIE school of thought (transactions cost economics) while the Pareto optimality reasoning used by Bliss and Stern (1982) and Skoufias (1995) is more neoclassical. The use of Pareto optimality reasoning is not restricted to older works such as Srinivasan (1989) and Srinivasan and Bell (1989).

Thus in summary the six moral reasoning strategies found in the study of rural Indian land tenancy are the neoliberal growth strategy; the human capabilities strategy; the redistributionist strategy; the transformationalist strategy; the social equality strategy; and the Pareto optimality criterion strategy. Of these, the transformationalist and the social equality strategies may be the least familiar to CJE readers. One can read Langley and Mellor (2002) for more background on the transformationalist strategy, and Kandiyoti (1999) on the social equality strategy.

These six strategies all use counterfactuals to conduct thought experiments based on real historical situations and/or empirical data. Sen is an interesting example who has used a wide range of these reasoning techniques over the years. He makes interesting but cautious comparisons of India with China, and of Kerala with other parts of India, for instance (Sen, 1996). Sen appears to be pluralist at the level of theory, as well as innovative and thoughtful in constructing moral arguments. A typical statement of purpose by Ramachandran indicates that moral reasoning is based not only on knowledge of one particular case, but also on knowledge of comparable cases, e.g.:

The purpose of this study is not to study the specific features of Kerala's experience only in order to try and establish Kerala's exclusiveness; it is to try and draw out lessons from Kerala's experience for the rest of India and, perhaps, for other developing countries. (Ramachandran, 1996, in Drèze and Sen, eds. 1996: 207-8).

I now want to point out two contradictions found in this literature. Firstly, some neoclassical economists have switched from neoliberal growth reasoning to other reasoning strategies, notably human capabilities approaches (Stiglitz, 2002a) while continuing to advocate fundamentally atomistic and universalistic modelling methods. Secondly, the large changes advocated by redistribution and transformation theorists will tend to be absolutely rejected by Pareto optimality reasoning because the latter presumes that any move, other than a small incremental change, will tend to harm someone. Thus in general there is a danger of contradictions (or incoherence) when two or more moral reasoning strategies are applied at the same time. 
Taking firstly the combination of human capabilities reasoning with neoliberal growth reasoning, Stiglitz provides an interesting example. Typically in Stiglitz's writing the two main reasoning strategies were Pareto optimality and neoliberal growth reasoning (e.g. Stiglitz, 1986). In recent years he has moved toward accepting the human capabilities approach, thus moving away from methodological individualism and toward realism. Stiglitz pointed out some dangers of Pareto-optimality reasoning in his article on social justice (2002a: 25). He suggests that technocrats' use of Pareto-style reasoning can actually mask real harm to groups of workers (ibid.). His concern is not only with Pareto optimality reasoning itself. It appears to also be that a technocrat may not be well equipped to do moral reasoning or to apply theory to practical situations. Nevertheless, the Pareto-optimality reasoning is widely used, is often applied with detailed nuances, and often comes in a complex package along with multifaceted explanatory arguments (e.g. Agrawal, 1999). Classic illustrations of the subjectivism found in traditional Pareto-optimality arguments are the reports by Srinivasan (1989, and with Bell in 1989) on bonded labour. O'Neill (1998) rejects this subjectivism and tends to undermine the use of Pareto optimality reasoning . Most importantly we have to realise that Stiglitz' move toward human capabilities would require him to begin to recognise locality-specific cultural differentiation, move away from universalistic models, and avoid global prescriptions for the kind of social situations that are locally and regionally diverse. In summary, neoliberal growth reasoning itself faces problems when combined with human capabilities reasoning because the former tends to be universalistic while the latter tends to pay attention to local detail. Furthermore it appears difficult to use Pareto optimality reasoning in its traditional guise without presuming to know too much about diverse social groups' subjectivities. However these claims would need to be the subject of further research and nuancing.

The movement toward human capabilities reasoning has been part of a broad and widely supported shift from economic-growth to human-development centred strategies for public policy. The dotted line in Table 2 (row 2) reminds us that there has also been a widespread consensus that NIE scholars often recognise or use insights from NCE and vice versa. In a sense this dual shift could lead toward bridging the normative gap with Marxists and feminists, since the aim of achieving valued human capabilities is a common over-arching aim of all schools (it is rather hard to oppose). Bhaduri (1983) illustrates some common ground between NIE and Marxist theoretical frameworks (Olsen, 2006). Similarly, the assumption that rights in private property must be protected creates common ground between Agarwal (2003) and the NCE and NIE schools. Sen (1993) and Alkire and Black (1997), as well as Nussbaum, have strongly advocated human capabilities reasoning while retaining a neoclassical orientation to some topics. Thus there is a lot of movement and change in socio-economic theories which can later be applied to the land tenancy and rural labouring topics.

Taking now the second contradiction, which is between Pareto optimality reasoning and redistributive reasoning, there is a deep problem. Pareto reasoning assumes that the 
subjectivities of the participants are 'given'. By making this assumption, it does not allow for subjective conceptions of 'harm' and 'benefit' to change during the process of social change. Instead, the 'given' actors' interests are affected incrementally but their fundamental social location cannot be changed or questioned. (If it were changed, the model would be invalid. If it were questioned, then the active moral attention of the subject would be invoked. The scientist's expertise would no longer be sufficient to resolve a problem, and a democratic dialogue would be needed. These dialogues with lay people are not envisioned by the Pareto optimality reasoning as currently used.) Yet land redistribution inevitably changes people's social position. Perhaps Pareto optimality will always oppose it.

This contradiction has led to some heated exchanges in the tenancy literature. Wolford (2008) argues, for example, that the World Bank's incremental (Pareto optimality inspired) land reform policy is absolutely opposed to the populist land reform policies. The former would merely clarify and ensure written land title, thus enabling the sale and rental markets in land to work better. The latter would redistribute land itself to other people, thus changing the social structure. For Wolford, the World Bank logic is insufficient as a moral reasoning strategy about land.

Another example relates to gender and access to land. Agarwal (2002, 2003a) has suggested a reallocation of land to women at both the Indian national level and in Andhra Pradesh state. This recommendation was perceived by Jackson as threatening the interests of the elders of rural Indian families who oversee the passing down of property through the lineage (Jackson, 2003; Agarwal, 2003b). It appears that the social equality reasoning of Jackson was combined with an implicit form of Pareto optimality principle - avoid harming anyone because there may be a backlash. Many non-feminists perceive feminist policies to threaten the interests of men. In the exchange between Jackson and Agarwal, it was also pointed out that older women and married women also may stand to lose out in some families if the young women take property away with them at the time of marriage. Specific dowry and inheritance practices of each locality have to be taken into account in conducting moral reasoning about this. For example in southern Andhra Pradesh the woman's dowry at time of marriage would not typically include any land. Instead it would include portable assets and cash, while brothers of the bride would tend to use land jointly with their parents and then inherit some of that land upon the father's death. If one is applying social equality reasoning or Pareto optimality reasoning, should one assume that these practices are not going to change? It would be false to assume that they are not changing. But it would also be false to be too optimistic about women's inheritance because there have not been wide improvements in women's access to land from 1947 to 2007 in India.

The social equality approach so far (illustrated by Jackson) suggests that we should refer to local empirical detail to find out what is feasible and practical for each local ethnic and cultural group. The Pareto optimality approach would tend to suggest that one should never threaten a vested interest. The redistribution approach taken by Agarwal $(2002,2003 a)$ tends to clash with these other two approaches. 
The reason for an apparent conflict is that the social equality approach can appear to mutely accept the structural relationships that are deep causes of economic and cultural inequality. Agarwal (2003b) showed the weaknesses of using merely a subjectivist reasoning strategy. She also argued that improving women's access to land will increase their productivity, leading to potential Pareto improvements after transfers have been made (i.e. after households share the benefits of the new crops). She advocates land redistribution policies strongly at a regional level within India because the transformations in gender relations, she argues, will benefit both men and women of all generations over the longer run.

The social equality viewpoint has different priorities from this kind of redistributionism. It tries not to let economic and commercial matters dominate within an argument about policy. Culture, tradition and habit need to be taken seriously, too, according to the social equality viewpoint and to many anthropologists. According to Jackson's viewpoint, also seen in other feminist writings (see Jeffrey, 2001; Rai, 1995), local specificities force researchers to avoid universalistic statements and sweeping advocacy (Menon, 2002). Kapadia (1995) at several points illustrates the local specificity of socio-economic formations based upon particular histories and concrete class-caste connections. Kapadia and Jackson, as well as Agarwal, have all conducted extensive local fieldwork and none of them would be accused of excessive universalism in their scientific research (see also the chapters in Kapadia, ed., 2002). Thus, the two moral reasoning strategies have come into conflict but are, in practice, probably compatible when brought to bear on a concrete and specific ethical situation. xvi Again this is an area for further research.

If attention is given to a range of moral reasoning approaches, perhaps combining two or three of them, then a serious discussion of norms and purposes, and of means and ends, can be begun. In this serious discussion lay accounts of 'the good' can be brought together with expert overview and some abstract account of a desirable trajectory. Since the transformation strategy allowed for changes in people's subjectivity and in their use of social discourses, it may make sense to combine this strategy with the redistribution strategy. In West Bengal, for example, it appears that the agrarian economy has evolved in ways that accept and build upon the tenancy reforms of previous decades (Banerjee, Gertler, and Ghatak, 2002). Vested interests of the past became stakeholders in the present economic system alongside the tenants. A democratic dialogue did occur, and the reforms were accepted. As in this example, it is unlikely that debates can be resolved at the level of peer-reviewed journals or expert commentary. Instead, deliberations that mix actors from the local, lay, and scientific arenas are useful.

The moral reasoning strategies have been listed at a very high level of abstraction. No resolution of the tensions between them can be found at such a high level. One might question Pareto optimality in general, because of its subjectivism and anti-realism, but still wish to avoid harm from any change in a particular area of life. But the answer to whether a change is deemed good would depend on the specific types of harm, to whom, and what 
offer of changed circumstances might be made available to them. Since in general changed policies imply a variety of changed opportunities, the no-harm condition cannot in general be assumed to apply. Our knowledge of harm is rooted in past conditions; it will be hard to predict the harm in the new conditions. We can know only of a tendency toward harm. As critical realists, Morgan and I have stressed the need for real-world interaction because overly theoretical policy prescriptions may not make sense for lay actors (Morgan and Olsen, 2008 forthcoming).

\section{Conclusion}

The paper has developed a moral economy research agenda. Although the different schools of thought are not easy to combine, there are insights about social norms and evaluative statements that are worth noticing in all four schools. The neoclassical school suffered from a contradiction between a professed value-neutrality and an underlying preference for higher productivity and economic growth. The new institutional economics school criticised government inefficiency, but was agnostic toward the distribution of land. The Marxist authors reasoned that improvements in human well-being would require both structural changes in land distribution and transformative discursive change. The changes in discourse would then enable people to question landlords' rights over property and rent, and to raise explicit political issues about workers' needs and rights. Finally, the feminist 'gender and development' school, which integrates insights from feminism and Marxism, has generated an explicit moral debate about priorities over land use and land ownership, as illustrated by the arguments of Agarwal and Jackson.

Some ontological work would be needed to develop an interdisciplinary economics with structure-agency dynamics that is sensitive to the non-money economy as well as to the market economy (Gasper, 2001). Dow (2004) suggests that a structured pluralism would attend to major social structures whilst using a multi-disciplinary explanatory framework. In my view, field based research and policy-related enquiry should and can complement the more philosophical and abstract meta-enquiry that is usually known as moral philosophy. Economists from all the schools would do well to respond to Sayer's suggestion that lay normativity needs more attention than philosophers have given it.

Three criticisms of the framework offered here should be dealt with before ending the paper. Firstly, it can be argued that the framework is too complex and wide-ranging to be viable. The danger, however, of narrower mono-disciplinary studies is that they cannot judge well the effect on the whole of any change in a part. In particular, Agarwal shows an admirable knowledge of culture, politics, society and economy. A real point of difference between her and Jackson was about how rapidly social structures of patriarchy can be changed in Andhra Pradesh. This can perhaps be converted into a new empirical question.

Secondly, it could be argued that the Indian women's tenancy issue has not been resolved. The role of a social scientist is not to resolve such an issue. They can take a position but their evaluations may need to be conditional, conjunctural, and temporary, in the sense that they 
are held subject to new knowledge. Another task, though, is to identify how the proposals arising from authors like Agarwal and Genicot open up new research questions, and to decide which of these is most pressing.

Thirdly, the stance of a scholar's value-neutrality could still be justified by making assertions about a strong division of labour in the social sciences. Many scholars oppose such a division of labour because it allows monodisciplinarity to support unwise policies (Allen and Thomas, eds., 2000, Ch. 1), and because it can dehumanise and isolate the researcher (Gasper, 2001, 2004). Unrealistic research is likely to result. In this paper I have opened up paths of pluralism - one via the bridging of schools of thought, and a second via making complex moral reasoning strategies coherent and consistent. Overall the possibilities for non-valueneutral development economics are vast.

The clear conclusion from this paper is that a pretense of value neutrality is going to be a barrier to good moral economy research. The study of land reform cannot simply be conducted independently of values, evaluations, and research about social norms and customs. We need research methods that integrate the study of values and social norms along with the study of how society works. It is preferable to have an explicit debate, as we have seen between Agarwal and Jackson, rather than separating out different schools within economics and finding it impossible to talk across the boundaries.

\section{References}

Agarwal, B. (1994). A Field of One's Own: Gender and Land Rights in South Asia. Cambridge, Cambridge University Press.

Agarwal, B. (2002). Are We Not Peasants Too? Land Rights and Women's Claims in India. Seeds 21. The Population Council, ISSN 073-6833, New Delhi.

Agarwal, B. (2003a). Gender and Land Rights Revisited: Exploring New Prospects via the State, Family and Market. Journal of Agrarian Change, 3, 184-224.

Agarwal, B. (2003b). Women's Land Rights and the Trap of Neo-Conservatism: A Response to Jackson. Journal of Agrarian Change 3:4, 571-585.

Agrawal, P. (1999). Contractual structure in agriculture. Journal of Economic Behavior $\mathcal{E}$ Organization 39(3): 293-325.

Aldridge, J. (1993). The Textual Disembodiment of Knowledge in Research Account Writing. Sociology 27(1): 53-66.

Alkire, S. and R. Black (1997). " A Practical Reasoning Theory of Development Ethics: Furthering the Capabilities Approach." Journal of International Development 9(2): 263279.

Allen, T. and A. Thomas (2000). Poverty and development into the 21st century. Oxford, The Open University in association with Oxford University Press.

Anderson, E. (1993). Value In Ethics And Economics. Cambridge, Mass. ; London, Harvard University Press.

Anderson, E. (2003). Sen, Ethics and Democracy. Feminist Economics 9(2): 239-262. 
Archer, M., Bhaskar, R., Collier, A., Lawson, T., and A. Norrie, Eds. (1998). Critical Realism: Essential Readings. London, Routledge.

Athreya, B. V., G. Djurfeldt, and S. Lindberg. (1990). Barriers Broken: Production Relations and Agrarian Change in Tamil Nadu. New Delhi, Sage.

Babbitt, S. (1993), Feminism and Objective Interests: The Role of Transformation Experiences in Rational Deliberation, ch. in Alcoff and Peters, eds., Feminist Epistemologies, NY and London: Routledge.

Banerjee, A. V., Paul J. Gertler, and Maitreesh Ghatak (2002). Empowerment and Efficiency: Tenancy Reform in West Bengal. Journal of Political Economy 110(2): 239-280.

Bardhan, P. (2005). Theory or Empirics in Development Economics. Economic and Political Weekly XL(40): 4333-4335.

Basu, A. (1992). Two Faces of Protest: Contrasting Modes of Women's Activism in India. Berkeley, University of California Press.

Basu, K. (2005). "New Empirical Development Economics: Remarks on Its Philosophical Foundations." Economic and Political Weekly XL(40): 4336-4339.

Begg, D. K. H., Fischer, S., and R. Dornbusch (2005), Economics, Maidenhead: McGraw-Hill.

Beneria, L. (1979). Reproduction, production and the sexual division of labour. Cambridge Journal of Economics 3: 203-225.

Beneria, L. (2003). Gender, development, and globalization: economics as if all people mattered. New York; London, Routledge.

Bhaduri, A. (1973). "A Study in Agricultural Backwardness Under Semi-Feudalism." Economic Journal: 120-137.

Bhaduri, A. (1983a). "Cropsharing as a Labour Process." Journal of Peasant Studies 10(2-3): 8893.

Bhaduri, A. (1983b). The Economic Structure of Backward Agriculture. London, Academic Press.

Bhaduri, A. (1986). "Forced Commerce and Agrarian Growth." World Development 14(2): 267272.

Bhaduri, A. (1997). Productivity, Production Relations, and Class Efficiency: Illustrations from Indian Agriculture. Economic Development and Agricultural Productivity. A. Bhaduri and R. Skarstein. Cheltenham, UK, and Lyme, USA, Edward Elgar.

Bhaskar, R. (1998). The possibility of naturalism: a philosophical critique of the contemporary human sciences. London; New York, Routledge.

Bhaskar, R. (2002). From Science to Emancipation, London: Sage. The Bhaskar Series.

Bliss, C.J. and Stern, N.H. (1982). Palanpur : the economy of an Indian village. Oxford: Clarendon Press.

Brass, T., and Marcel Van der Linden. 1998. Free and Unfree Labour: The Debate Continues. Berlin, Peter Lang AB.

Brass, T. (2001) 'At their perfect command'? The struggle of/(over) post-emancipation rural labour. Journal Of Peasant Studies, 28:3, 155-177.

Brinkmann, S. (2005). "Psychology's Facts and Values: A Perennial Entanglement." Philosophical Psychology 18(6): 749-765.

Caldwell, B. J. (1994). Two Proposals for the Recovery of Economic Practice. New Directions in Economic Methodology. Ch. 7 in ed. R. E. Backhouse. London, Routledge: pages 137-153. 
Chang, H.-J. (2003). The Market, the State and Institutions, chapter 2 in Rethinking Development Economics. H.-J. Chang. London, Anthem Press.

Chindarkar, N. (2007), A Qualitative Comparative Analysis of Farmers' Suicides in Andhra Pradesh, India, Methodological Innovation Online, 2:2.

DaCorta, L., and Davuluri Venkateswarlu. (1999). Unfree Relations and the Feminisation of Agricultural Labour in Andhra Pradesh, 1970-95. Journal of Peasant Studies 26(2-3): 73139.

Danermark, B. et al. (2001). Explaining Society: An introduction to critical realism in the social sciences. London, New York, Routledge.

Drèze, J. and A. Sen (1995). India: economic development and social opportunity. Delhi; Oxford, Oxford University Press 1995.

Drèze, J. and A. Sen (1997). Indian development: selected regional perspectives: a study prepared for the World Institute for Development Economics Research of the United Nations University. Delhi, Oxford University Press.

Drèze, J. and A. K. Sen (2002). India: development and participation. Oxford, Oxford University Press.

Dow, S. (2004) Structured Pluralism, Journal of Economic Methodology, 7:3.

Ellis, F. (1993). Peasant economics: farm households and agrarian development. Cambridge, England, Cambridge University Press.

Epstein, T. S. (1962). Economic Development and Social Change in South India. Manchester, Manchester Univ. Press.

Epstein, T. S. (1973). South India: Yesterday, Today and Tomorrow: Mysore Villages Revisited. London, Macmillan.

Epstein, T. S., A. P. Suryanarayana, et al. (1998). Village Voices: Forty Years of Rural Transformation in South India. New Delhi, Thousand Oaks and London, Sage.

Fairclough, N. (2001). Language and power, 2nd edition. Harlow, England, Longman.

Fay, B. (1987) Critical Social Science: Liberation and its Limits, London: Polity Press.

Gasper, D. (2001). Interdisciplinarity: building bridges, and nurturing a complex ecology of ideas.

The Hague, The Netherlands, Institute of Social Studies. Working Paper 331.

Gasper, D. (2004). The ethics of development : from economism to human development. Edinburgh, Edinburgh University Press.

Genicot, G. (2002). Bonded labor and serfdom: a paradox of voluntary choice. Journal of Development Economics 67(1): 101-127.

Giri, A.K. (2004), "The Calling of a Creative Transdisciplinarity”, chapter 16 in Creative Social Research: Rethinking Theories and Methods, Delhi: Vistaar Publ. and Lanham Maryland: Lexington Books (2005), ed. A. K. Giri.

Habermas, J. (1998, original 1996). The Inclusion of the Other. Studies in Political Theory. Cambridge: CUP.

Hands, D. W. (2001), Reflection Without Rules: Economic methodology and contemporary science theory. Cambridge: Cambridge University Press.

Harriss-White, B. (2007), "Poverty And Capitalism", paper for the Conference on Poverty and Capitalism, Manchester, Global Poverty Research Group, www.gprg.org ; 
www.sed.manchester.ac.uk/research/events/conferences/povertyandcapital/harrisswhite.pdf , accessed July 2007.

Harriss-White, B. (2006). 'Poverty and Capitalism' Economic and Political Weekly, XLI: 13 ,April 1st, pp1241-6.

Hodgson, G. (2000). "What is the Essence of Institutionalism?" Economy and Society XXXIV: 2, June. Pages 317-329.

Hodgson, G. M. (2004). The Evolution of Institutional Economics: Agency, Structure and Darwinism in American Institutionalism. London, Routledge.

Hogger, R. (2004) 'Understanding Livelihood Systems as Complex Wholes', pp. 35-53 in Ruedi Baumgartner and Ruedi Hogger, eds, In Search of Sustainable Livelihood Systems: Managing Resources and Change. London: Sage Publications.

Jackson, C. (2004) Projections and Labels: A Reply to Bina Agarwal, Journal of Agrarian Change, 4:3, 387-388.

Jackson, C. (2003) Gender Analysis of Land: Beyond Land Rights for Women?, Journal of Agrarian Change, 3:4, 453-480.

Jackson, C. (2002). Disciplining gender? World Development 30(3): 497-509.

Jackson, C. (1996) Rescuing gender from the poverty trap, World Development, 24:3, 489-504.

Jeffery, P. (2001). A uniform customary code? Marital breakdown and women's economic entitlements in rural Bihar. Contributions to Indian Sociology 35(1): 1-32.

Kabeer, N. (1995). Reversing Reality. London, Sage.

Kalpagam, U. (1994). Labour and Gender: Survival in Urban India. London, New Delhi and Thousand Oaks, Sage.

Kandiyoti, D. (1999) Poverty in Transition: An ethnographic critique of household surveys in post-Soviet Central Asia, Development And Change, 30:3, 499-524.

Kapadia, K. (1995). Siva and Her Sisters: Gender, Caste and Class in Rural South India. Boulder and Oxford, Westview Press.

Kapadia, K., Ed. (2002). The Violence of Development. London, Zed Books.

Lacey, H. (1999). Is Science Value Free? Values and Scientific Understanding. London \& New York, Routledge.

Langley, P., and M. Mellor (2002). 'Economy', Sustainability and Sites of Transformative Space, New Political Economy, 7:1.

Lawson, T. (1994). A Realist Theory for Economics. New Directions in Economic Methodology. Ch. 13 in ed. R. E. Backhouse. London, Routledge: 257-285.

Lawson, T. (1997). Economics and reality. London; New York: Routledge.

Lloyd, E. A. (1995). Objectivity and the double standard for feminist epistemologies. Synthese 104(3): 351.

MacIntyre, A. (1985 (orig. 1981)). After Virtue: A Study in Moral Theory. London, Duckworth Publishers.

Majid, N. (1994). Contractual Arrangements in Pakistani Agriculture: A study of share tenancy in Sindh. Oxford, Oxford University.

Mäki, U. (1994). Reorienting the assumptions issue. New Directions in Economic Methodology. Ch. 12 in R. E. Backhouse. London, Routledge: 236-256. 
Mearns, R. (1999). "Access to Land in Rural India: Policy Issues and Options." Policy Research Working Paper 2123, The World Bank, pages 1-50.

Mencher, J. P. (1978). Agriculture and social structure in Tamil Nadu: past origins, present transformations, and future prospects. Durham, N.C., Carolina Academic Press.

Menon, N. (2002). Universalism Without Foundations. Economy and Society 31(1): 152-169.

Mies, M. (1982). The Lace Makers of Narsapur: Indian Housewives Produce for the World Market. London, Zed Books.

Mies, M. (1998, orig. 1989). Patriarchy and accumulation on a world scale: women in the international division of labour. London, Zed.

Mookherjee, D. (2005). "Is There Too Little Theory in Development Economics Today?" Economic and Political Weekly XL(40): 4328-4333.

Morgan, J., and W. Olsen, (2007) "Defining Objectivity In Realist Terms: Objectivity as a Second-Order "Bridging" Concept, Part 1", Journal of Critical Realism, 6:2, Accessed 2007 at http://www.equinoxjournals.com/ojs/index.php/JCR/ .

Morgan, J., and W. Olsen, (2008) "Defining Objectivity In Realist Terms: Objectivity as a Second-Order "Bridging" Concept, Part 2: Bridging Into Action", Journal of Critical Realism, 7:1, forthcoming 2008 at http://www.equinoxjournals.com/ojs/index.php/JCR/

Ng, Y.-K. and Singer, P. (1981): An Argument for Utilitarianism, Canadian Journal of Philosophy 11 (2), pp. 229-329.

Nelson, J., A. (1995). Feminism, objectivity and economics. London, Routledge.

Nelson, J. A. (2003). Once More, With Feeling: Feminist Economics and the Ontological Question. Feminist Economics 9(1): 109-118.

Nussbaum, M. (1993). Non-Relative Virtues: An Aristotelian Approach. The Quality of Life. M. Nussbaum and A. K. Sen. Oxford, World Institute for Development Economics Research (WIDER) of the UN University, and Clarendon Press: 242-269.

Nussbaum, M. (1999). "Women and equality: the capabilities approach." International Labour Review 138(3).

Nussbaum, M. (2000). Women and Human Development: The Capabilities Approach. Cambridge and NY, Cambridge University Press.

Nussbaum, M. (2001). Upheavals of Thought: The Intelligence of Emotions. Cambridge, Cambridge University Press.

Olsen, W. K. (1996). Rural Indian Social Relations. Delhi, Oxford University Press.

Olsen, W. K. and J. Morgan (2005). "A Critical Epistemology of Analytical Statistics: Addressing the Sceptical Realist." Journal for the Theory of Social Behaviour 35(3): 255284.

Olsen, W.K. (2007), "Pluralist Methodology for Development Economics: The Example of Moral Economy of Indian Labour Markets", Journal of Economic Methodology, 14:1, 5782, March.

Olsen, W.K. (2006). Pluralism, Poverty and Sharecropping: Cultivating Open-Mindedness in Development Studies, Journal of Development Studies, 42(7): 1130-1157.

Olsen, W.K. (2005), Moral Political Economy and Poverty: Four Theoretical Schools Compared, Global Poverty Research Group, Working Paper No. 31, www.gprg.org. 
Olsen, W.K. and S. Mehta (2006a) A Pluralist Account of Labour Participation in India, Global Poverty Research Group, Working Paper No. 42, www.gprg.org. (also published at Radical Statistics, vol. 93, 2006, www.radstats.org.uk)

Olsen, Wendy, and Smita Mehta (2006b) “The Right to Work and Differentiation in Indian Employment", Indian Journal of Labour Economics, 49:3, July-Sept., 2006, pages 389-406.

Pareto, V. (1971, orig in Italian 1909, Translated by Ann S. Schwier). Manual of political economy. New York, A.M. Kelley.

Pawson, R. (1998). A Measure for Measures: A Manifesto for an Empirical Sociology. London, Routledge.

Pawson, R. and N. Tilley (1997). Realistic evaluation. London; Thousand Oaks, Calif., Sage.

Jackson, C. and R. Pearson, eds. (1998). Feminist visions of development : gender, analysis and policy. London, Routledge.

Jejeebhoy, S. J. and Z. A. Sathar (2001). "Women's autonomy in India and Pakistan: The influence of religion and region." Population and Development Review 27(4): 687.

O'Neill, J. (1998). The Market: Ethics, Knowledge and Politics. London, Routledge.

Patomaki, H. (2006). "Realist Ontology For Futures Studies." Journal of Critical Realism 5(1): 131.

Poitevin, G. and H. Rairkar. Eds. (1993, orig. French 1985). Indian Peasant Women Speak Up. London, Orient Longman, trans. Michel Leray.

Putnam, H. (2002), The Collapse of the Fact/Value Dichotomy. Cambridge, MA: Harvard University Press.

Putnam, H. (2003), For Ethics and Economics without the Dichotomies, Review of Political Economy, 15(3), 395-412.

Rai, S. M. (1995). "Women Negotiating Boundaries - Gender, Law and the Indian State." Social $\mathcal{E}$ Legal Studies 4(3): 391-\&.

Railton, P. (1997), "Moral Realism”, ch. 8 in Moral Discourse and Practice: Some Philosophical Approaches, Darwall, S., A. Gibbard, and P. Railton, eds., NY: Oxford University Press, pages 137-166.

Ramachandran, V. K. (1990). Wage Labour and Unfreedom in Agriculture: An Indian Case Study. Oxford, Clarendon Press.

Ramachandran, V. K. (1996). On Kerala's Development Achievements. Indian Development: Selected Regional Perspectives. J. Drèze and A. K. Sen. Oxford and Delhi, Oxford University Press: 205-356.

Rew, A. and S. Khan (2006). The Moral Setting for Governance in Keonjhar: The Cultural Framing of Public Episodes and Development Processes in Northern Orissa, India. Oxford Development Studies 34(1): 99-115.

Rolfe, G. (2006). A critical realist rationale for using a combination of quantitative and qualitative methods. Journal Of Research In Nursing 11(1): pp. 79-80.

Ryan, P. (2005). Meckler and Baillie on Truth and Objectivity. Journal of Management Inquiry 14(2): 120-126.

Sayer, A. (1992). Method in Social Science. London, Routledge.

Sayer, Andrew (2000a). Realism and Social Science. London: Sage. 
Sayer, A. (2000b). Moral Economy and Political Economy. Studies in Political Economy, Spring, 79-103.

Sayer, A. (2005) mimeo, 'Restoring the Moral Dimension: Acknowledging Lay Normativity', British Sociological Association conference, York.

Sen, A. 1964), Size of Holding and Productivity, Economic and Political Weekly, 16: 323-326.

Sen, A. 1966), Peasants and Dualism With and Without Surplus Labour, Journal of Political Economy, 74: 425-450.

Sen, A. (1979) "Equality of What?", The Tanner Lecture On Human Values, Stanford University, May 22.

Sen, A. K. (1980). Description as Choice. Oxford Economic Papers 32.

Sen, A.K. (1993). Positional Objectivity. Philosophy and Public Affairs 22: $126-45$.

Sen, A. K. (1996). Radical Needs and Moderate Reforms. Indian Development: Selected Regional Perspectives. J. Drèze and A. K. Sen. Oxford and Delhi, Oxford University Press: 1-32.

Sengupta, S. and H. Gazdar (1996). Agrarian Politics and Rural Development in West Bengal.

Indian Development: Selected Regional Perspectives. J. Drèze and A. K. Sen. Oxford and Delhi, Oxford University Press: 129-204.

Shankar, K. (1999). 'Tenancy Reforms: Rhetoric and Reality'. Economic and Political Weekly, Nov. 20-26, online at www.epw.org.in, downloaded Oct. 2003. 34 Issue: 46-47 Pages: 3264-3265.

Sharma, H. R. (2000). "Tenancy Relations in Rural India: A Temporal and Cross-Sectional Analysis." Indian Journal of Agricultural Economics 55(3).

Singer, P., Ed. (1994). Ethics. Oxford, Oxford Univ. Press.

Singh, M. (1995). Uneven Development in Agriculture and Labour Migration: A Case of Bihar and Punjab. Shimla, Indian Institute of Advanced Study.

Skoufias, E. (1995). Household Resources, Transaction Costs, and Adjustment through Land Tenancy. Land Economics 71(1): 42-56.

Smith, M. J. (1998). Social science in question: towards a postdisciplinary framework. London; Thousand Oaks, Calif., Sage Publications in association with the Open University.

Srinivasan, T. N., and Clive Bell (1989). "Interlinked Transactions in Rural Markets: An Empirical Study of Andhra Pradesh, Bihar and Punjab." Oxford Bulletin of Economics and Statistics 51: 73-84.

Srinivasan, T. N. (1989). On Choice Among Creditors and Bonded Labour Contracts. The Economic Theory of Agrarian Institutions. P. K. Bardhan. Oxford, Clarendon Press: 203220.

Stiglitz, J. (1986). The New Development Economics, World Development 14(2): 257-265.

Stiglitz, J.E. (1974). Incentives and Risk Sharing in Sharecropping. Review of Economic Studies 41:2 219-255.

Stiglitz (2002a). Employment, Social Justice, and Societal Well-Being, International Labour Review 141(1-2): 9-29.

Stiglitz, J. E. (2002b). Globalization and its discontents. London, Allen Lane.

Swaminathan, P. (2002). The Violence of Gender-Biased Development: Going Beyond Social and Demographic Indicators. The Violence of Development: The Politics of Identity, Gender 
and Social Inequalities in India. In K. Kapadia. London, Delhi and NY, Kali Books and Zed Press: 69-141.

Titscher, S., M. Meyer, et al. (2000). Methods of Text and Discourse Analysis. London, Sage Publications.

Todaro, M.P. (1997) Economic Development, London: Longman.

Veblen, T. (1899). The Theory Of The Leisure Class: An economic study of institutions. London, Allen and Unwin 1970.

Venkateswarlu, D. and L. Dacorta (2001). "Transformations in the Age and Gender of Unfree Workers on Hybrid Cotton Seed Farms in Andhra Pradesh." Journal of Peasant Studies 28(3): 1-36.

Walby, S. (2001). Against Epistemological Chasms: The Science Question in Feminism Revisited. Signs 26(2): 485-509.

Walsh, V. (2003). Sen After Putnam. Review of Political Economy 15(3): 315-394.

Wolford, W. (2008). Land Reform in the Time of Neoliberalism: A Many-Splendored Thing. Chapter in Privatization. B. Mansfield. Oxford, Blackwell. [article also appeared in Antipode 2007]

Williams, M. (2005). Situated Objectivity. Journal for the Theory of Social Behaviour 35(1): 99-120. Wolfe, A. (2001). Moral freedom: the impossible idea that defines the way we live now. New York; London, W.W. Norton.

\footnotetext{
${ }^{\mathrm{i}}$ Note that this paper deals with marxism as expressed by economists based in India, or doing research on India, not in/on other countries. Therefore some strands of marxism are missed out.

ii The author's own calculations; National Sample Survey $55^{\text {th }}$ round, 1999, raw data weighted to national level.

iii The author's own calculations; National Sample Survey $55^{\text {th }}$ round, 1999, raw data weighted to national level.

${ }^{\text {iv }}$ Structuralism can be found in numerous places to a greater or lesser extent. In marxism in India it is a widespread foundational assumption. Here structures of class and nation are understood to have impacts on the beings within those structures, such as workers and voters. Structures are also thought to be more than the sum of their parts; they have holistic qualities and require historical study. Thus there is a close affiliation of structuralism with marxism. However structuralism is also found in feminism, in sociology and in some other areas of social science. Here it is less focused on social class and tends simply to use the analytical term 'structure' to refer to durable sets of relationships and their overall qualities. I try to use the term structuralist in consistent ways whilst recognising this complex background to its use.

' The category 'all' feminists, in the context of the study of rural India, includes a variety of neoclassical feminists such as Kingdon and others who are not easily classified. The paper deals only with one sub-group of feminist economics, the GAD school, and does not treat other feminists in detail.

${ }^{\mathrm{vi}}$ Ethical elements use ethics to judge the worth or goodness of outcomes; evaluative statements place affective connotations on states of affairs; and normative statements prescribe what is, or would be, good or bad in a given situation. When I use the term normative, I do not mean 'normal' nor do I refer only to the dominant norms of a society. I mean that the writer is invoking a norm that they wish to be associated with. This could potentially be a divergent or unusual norm, but is often a reference to a standard social norm.
} 
vii The reasoning used by Veblen (1899) and Hodgson (2000) as old institutionalists may actually resolve this incoherency found in new institutional economists' writings. I have not yet found an exemplar to illustrate old institutionalism in the Indian rural context, but it is a rich area for future research. The old institutionalists look at the evolution of institutions from both social and historical vantage points, as well as economic ones, and so are vastly different from the New Institutional Economics described here (Hodgson, 2000; 2004). The lack of theory and context that has been noticeable in NIE may be one reason Indian economists have been concerned about gaps in the NIE. NIE is known among development economists as the 'New Development Economics' (Stiglitz, 1986; Mookherjee, 2005; Basu, 2005; Bardhan 2005). Formalist NIE, too, whilst having many advantages is still in danger of being ahistorical and weak in its ontology (Chang, 2003; Olsen, 2007). Specifically a set of mathematical equations leading to a model with equilibria may seriously distort one's knowledge of a real economy in favour of knowledge of a stylised model. The ontological weakness is thus a lack of realism and a tendency to 'empirical realism' (Lawson, 1997).

${ }^{\text {viii }}$ Walsh (2003: 321-3, 329) notes that economists often widely exhibit logical positivism. Smith (1998, ch. 3) clarifies the role of the fact-value dichotomy in each of three sub-schools of positivism.

${ }^{\text {ix }}$ Note that beliefs are not the same as knowledge. One's knowledge offers an edifice supporting successful actions. For example, one might know how to cut wood, how to accurately describe the eviction of a farmer, and how to convince others of a political position. One's beliefs are of two types: firstly the claims that one thinks are true but which are subject to further checking with evidence, as in 'I believe the farmer is exploited and I am checking out that hypothesis'; and secondly some fundamental assumptions which one believes without direct evidence and without seeking further evidence ('I take it as given that the property laws must be obeyed'). It is important to distinguish beliefs from knowledge so that science can seek to improve beliefs through gaining knowledge. A scientist will tend to challenge the second type of belief. Beliefs are fallible.

${ }^{x}$ Several methodological issues are raised by such points. However I am trying to convey the gist of the argument and move on, so will not pursue those issues. See writings on critical discourse analysis such as Titscher, et al., for further discussion (2000).

${ }^{x i}$ A detailed defence of utilitarianism is provided by $\mathrm{Ng}$ and Singer (1981). The rejection of utilitarianism by many other authors does not stop it from being an important complex reasoning strategy.

xii The word 'moral' is used by philosophers working in this area, but the word 'ethics' is often used in the same sorts of contexts by empirical researchers such as Wolfe (2001). Wolfe argues that not only are people's ethical beliefs 'about' a variety of types of people, i.e. 'moral' in the philosophers' technical sense, but also are responsive to the effects of one's beliefs and actions upon other people. The word 'ethical' usually refers to this work of reasoning-within-a-scene (in which one is also taking part), whereas the word 'moral' tends to be used when someone is trying to gain a God's-Eye view of that complex scene. We thus have the phrases 'ethical orientations' but 'moral philosophy'. Nevertheless the two words are often substitutable for each other in practice. 
xiii See also the website of the International Development Ethics Association (IDEA), http://www.developmentethics.org/. Accessed April 2008. The IDEA is a cross-cultural group of philosophers, social scientists, and practitioners who apply ethical reflection to global development goals and strategies and to North/South relations.

${ }^{\text {xiv }}$ This paper does not cover the wide range of policy arguments about land reform, land ceilings, land record modernisation and other policy changes currently under consideration. There is not enough space.

${ }^{\mathrm{xv}}$ Specifically, a claim that depending on markets can be a way to solve some economic problems; a belief that the state can act benignly by shaping the arena within which markets work; and by arguing that the invisible hand has been disabled through India's planning process. Sen does not use utilitarianism lightly and he does not use atomistic economic models so he has by now diverged considerably from the neoclassical school of thought. ${ }^{x v i}$ An important area of difference is that authors using the social equality approach usually focus on subjectivity as a matter that is irreconcilable with objectivism, whereas the human capabilities approach is more open to a defusing of the separateness of that which is considered 'subjective' versus that which is considered 'objective'. 